\title{
ABSTRAK \\ PEREMPUAN DALAM ARENA KEKERASAN DOMESTIK \\ (Studi Dokumen Penyebab Kekerasan pada Perempuan dalam Rumah Tangga di Pulau \\ Bangka)
}

Oleh : Sujadmi*l

Tulisan ini mencoba untuk menganalisis berbagai bentuk kekerasan yang terjadi pada perempuan dalam rumah tangga atau keluarga. Lebih lanjut mencoba menggali kemungkinan penyebab yang melatarbelakangi terjadinya tindak kekerasan pada perempuan. Mansour Fakih mengemukakan bahwa pada dasarnya penyebab terjadinya kekerasan terdiri atas dua faktor yakni internl dan eksternal. Berangkat dari pandangan tersebut, maka tulisan ini akan mencoba mengkajinya melalui studi dokumentasi. Data-data yang digunakan untuk melakukan analsis adalah hasil penelusuran dokumentasi dari beberapa sumber. Hasil analisis menyebutkan bahwa tindak kekerasan yang dialami oleh perempuan di Pulau Bangka mayoritas disebabkan oleh faktor internal yakni terkait persoalan ekonomi rumah tangga. Lebih lanjut adanya pandangan tabu akan persoalan keluarga jika dipublikasikan sehingga perempuan cenderung lebih memilih diam dan tidak melaporkan pada pihak yang berwajib. Disini menunjukkan adanya faktor internal dan eskternal baik dari sisi perempuan maupun keluarga itu sendiri.

\section{Keywords : Perempuan, KDRT dan Ekonomi}

1 Dosen Jurusan Sosiologi Fakultas Ilmu Sosial dan Ilmu Politik Universitas Bangka Belitung

\section{A. Pendahuluan}

Kehidupan bersama yang terdiri atas orang tua (ayah/suami, ibu/istri) dan anak yag diikat oleh sebuah ikatan perkawinan disebut sebgai keluarga. Keluarga merupakan sebuah kelompok sosial terkecil yang selalu menjadi dambaan atau impian dari setiap individu dalam kehidupan bermasyarakat. Secara ideal keluarga merupakan tempat dimana individu mendapatkan kenyamanan baik secara materi maupun immateri. Setiap individu mendambakan kehidupan keluarga yang harmonis. Sebuah keluarga dikatakan harmonis ketika seluruh anggota keluarga merasa bahagia. Perasaan bahagia tersebut ditandai dengan tidak adanya konflik atau kekecewaan dan kepuasan terhadap seluruh keadaan anggota keluarga. Kepuasan terhadap keadaan yang dimaksud adalah baik keadaan secara fisik, mental, emosi dan sosial ekonomi.

Keluargayang harmonis memilikikekukuhan yang relatif lebih tinggi yang dipengaruhi oleh beberapa faktor. Faktor yang dimaksud diantaranya bahwa setiap anggota keluarga memiliki komitmen, kesediaan, mengungkapkan apresiasi, mengembangkan spiritualitas dan dapat menyelesaikan konflik. Faktor terakhir merupakan yang sangat menentukan akan keharmonisan dalam sebuah keluarga yaitu mampu tidaknya anggota keluarga terutama antara suami dan istri dalam menyelesaikan sebuah konflik.

Konflik dalam rumah tangga atau keluarga cenderung menimbulkan adanya tindak kekerasan terhadap anggota keluarga lainnya baik itu pada suami, istri ataupun anak sebagai korban. Tindak kekerasan senantiasa terjadi terhadap pihak-pihak yang dinilai lemah. Pada kasus rumah tangga pihak yang dimaksud yakni pada perempuan (istri) dan anak. Perempuan dan anak seringkali menjadi korban tindak kekerasan mengingat posisinya dalam struktur keluarga cenderung dianggap oleh masyarakat sebagai pihak yang berada pada kelas bawah yaitu berada 
dibawah kuasa laki-laki/suamu/ayah.

Rumah tangga merupaka ranah domestik yang secara sosio kultur dikonstruksikan sebagai ranahnya perempuan. Kondisi ini terjadi mengingat dalam budaya masyarakat memegang sistem pembagian kerja secara seksual, dimana perempuan ditempatkan di ranah domestik dan laki-laki pada ranah publik. Pembagian peran seperti ini secara tidak langsung telah menumbhkan tindak kekerasan yang seringkali terselubung bahkan para korban banyak yang berdalih sebagai bentuk ketaatan terhadap pelaku karena adanya ikatan perkawinan. Dengan demikian banyak sekali kasus kekerasan yang terjadi akan tetapi tidak terdata atau sulit untuk ditangani karena sifat tertutup dari para korban dan pelaku.

Data Komnas Perempuan mencatan bahwa tahun 2016 terdapat laporan tindak kekerasan terhadap perempuan sebanyak 259.150 kasus yang tersebar di 34 provinsi. Data tersebut tentunya lebih sedikit dibandingkan dilapangan mengingat masih banyak kasus yang belum atau tidak dilaporkan. Angka tindak kekerasan yang dialami oleh perempuan dan anak ii setiap tahunnya terus mengalami peningkatan. Lebih miris lagi bahwa para pelakunya adalah anggota keluarga sendiri.

Lebih lanjut dari adanya tindak kekerasan dalam rumah tangga ini mengacu pada meningkatnya angka perceraian. Berdasarkan data dari 359 Pengadilan Agama (PA) menunjukkan terdapat 245.548 kasus perceraian yang dilatarbelakangi oleh tindak kekerasan. Tindak kekerasan ini dialami oleh pihak perempuan sehingganya tidak sedikit dari kasus-kasus perceraian yang diajukan ke PA yakni dari pihak istri atau perempuan.

Pada wilayah kepulauan Bangka Belitung sendiri, angka kekerasan terhadap perempuan dalam rumah tangga setiap tahunnya pun terus mengalami peningkatan.kekrasan terhadap perempuan dalam keluarga ini berpotensi terjadi kapanpun dan dimanapun. Berdasarkan data dari dinas Pemberdayaan Perempuan, Perlindungan Anak pada tahun 2016 terdapat 202 kasus yang terdiri atas 90 kasus kekrasan dalam rumah tangga (KDRT), perkosaan 90 kasus, pencabulan 64 kasus, trafiking 2 kasus dan lainnya 49 kasus. Kasus tersebut yang menjadi korban mayoritas anak dan perempuan yang pelakunya adalah anggota keluarga sendiri.

Data-data tersebut menunjukkan bahwasannya kekerasan terhadap perempuan merupakan permasalahan yang mencemaskan pada setiap daerah bahkan negara (Djannah dkk, 2007: 1). Persoalan perempuan yang dialami dalam keluarga tentunya bukan lagi menjadi masalah privat atau domestik dalam setiap keluarga tersebut melainkan menjadi maslah sosial yang perlu mendapat perhatian serius dari berbagai pihak. Selama banyak sekali faktor yang diduga sebagi pemicu terjadinya tindak kekerasan yang dialami oleh perempuan dalam keluarga. Meskipun demikian, belum ada solusi atau tindakan yang dinilai cukup efektif dan efisien guna menekan tingginya angka kekerasan dalam rumah tangga yang dialami oleh anak dan perempuan. Berdasrkan pemaparan tersebut diatas, maka tuisan ini akan mencoba melakukan analisis penyebab terjadinya tindak kekerasan terhadap perempuan dalam ranah domestik. Analsis dilakukan pada data-data yang ditelusuri dari beberapa sumber dokumentasi baik pemerintah maupun media.

\section{B. Perempuan dan Keluarga}

Perempuan dan keluarga merupakan dua unsur yang tidak dapat dipisahkan. Pada setiap masyarakat tentunya memiliki kebiasaan atau kebudayaan yang beragam. Keberagaman budaya ini menimbulkan adanya perbedaan dalam sistem pembagian peran yang diterapkan dalam kehidupan keluarga maupun masyarakat luas. Perbedaan ini tidak terlepas dari adanya proses sosialisasi yang dilakukan dalam keluarga yang kemudian berkembang dalam kehidupan sekitar kelarga yakni masyarakat secara lebih luas. Sosialisasi dalam keluarga memegang peran yang sangat penting dalam setiap individu dan kelompok masyarakat memaknai terkait sistem pembagian kerja atau gender. 
Pembagian peran yang terjadi antara perempuan dan laki-laki tentunya memiliki perbedaan. Keduanya secara biologis berbeda karenanya peran-peran yang diharapkan dalam masyarakat pun secara sosiologis berbeda dan karenanya sosialisanya pun berbeda. Perbedaan sosialisasi ini terjadi baik yang dilakukan dalam keluarga maupun lingkungan sosial yang lebih luas yakni masyarakat (Ihromi, 2004: 43-44).

Menurut Scanzoni dan Scanzoni (dalam Ihromi, 2004: 44) laki-laki diharapkan melakukan peran yang bersifat instrumental yaitu berorientasi pada pekerjaan untuk memperoleh nafkah (task oriented), sedangkan perempuan diharuskan untuk melakukan peran yang sifatnya ekspresif, yaitu berorientasi pada emosi manusia serta hubungannya dengan orang lain (people oriented). Pembagian peran yang demikian berimplikasi pada perempuan yang senantiasa ditempatkan pada ranah domestik. Domestifikasi perempuan terjadi karena kultur yang terjadi pada masyarakat senantiasa dinilai sebagai sebuah kodrat atau suatu hal yang tidak dapat dirubah.

Pada kehidupan sosial budaya masyarakat di Indonesia khususnya di Pulau Bangka, perempuan dinilai memegang peran yang cukup besar dalam kehidupan rumah tangga atau keluarga. Pada lingkup ini tentunya perempuan dipandang sebagai pihak yang berwenang pada ranah domestik. Meskipun demikian, tidaklah sedikit kaum perempuan khususnya di Pulau Bangka yang juga turut bekerja di ranah publik. Ranah publik yang dimaksud disini adalah pada ranah ekonomi. Keterlibatan perempuan pada ranah ekonomi ini nampak pada adanya aktivitas atau keterlibatan perempuan sebagai pekerja atau buruh pada beberapa sektor. Sektor yang dimaksud diantaranya sebagai buruh pada kebun kelapa sawit, buruh timah inkonvensional (TI), buruh lepas atau harian dan lain sebagainya. Selain itu juga tidak sedikit yang terlibat dalam bidang jasa atau perdagangan hasi-hasil karya atau industru rumah tangga.

Kondisi pembagian peran atau kerja secara seksual tersebut semakin terinstitusionalisasikan kala pada kehidupan keluarga sistem tersebut terus direproduksi dari waktu ke waktu. Keluarga yang merupakan tempat dilakukannya sosialisasi untuk pertama kali memiliki andil yng cukup besar dalam diterapkannya sistem domestifikasi pada pihak atau kaum perempuan dalam kehidupan sosial kemasyarakatan.

\section{Faktor Penyebab Terjadinya Tindak Kekerasan Dalam Rumah Tangga \\ 1. Gambaran Kekerasan Dalam Rumah Tangga di Pulau Bangka}

Tindak kekerasan yang dialami perempuan dalam rumah tangga atau yang disebut dengan KDRT disebabkan oleh beberapa faktor. Dampak dari adanya KDRT ini tidak sedikit berujung pada gugatan perceraian. Sebagai contoh di Kabupaten Bangka Tengah, data pada dua tahun terakhir menunjukkan peningkatan pada data perceraian yang masuk ke Pengadilan Agama Bangka Tengah. Tabel 1 menunjukkan bahwa hampir pada setiap kecamatan yang ada di Kabupaten Bangka Tengah dalam kurun waktu dua tahun terakhir cenderung mengalami peningkatan. Semakin meningkatnya gugatan perceraian ini, PA Bangka Tengah menyampaikan bahwa sebagian besar dilatar belakangi oleh adanya tindak KDRT.

Selain di Kabupaten Bangka Tengah, daerah lain di Pulau Bangka yang angka perceraiannnya juga relatif tinggi adalah di Kabupaten Bangka Barat dan Kabupaten Bangka Selatan. Gambaran kedua kabupaten tersebut juga tidak jauh berbeda dengan kabupaten Bnagka Tengah. Kasuskasus kekerasan yang dialami perempuan dalm rumah tanggapun juga cukup tinggi. Kondisi tersebut juga berdamapak pada tingginya angka perceraian dengan alasan KDRT. Bangka Barat merupakan salah satu kabupaten yang beberapa waktu terakhir ini banyak sekali ditemukan kasus tindak kekerasan yang dilakukan suami terhadap istri. 
Tabel 1. Data Perceraian Pengadilan Agama Kabupaten Bangka Tengah

\begin{tabular}{|c|c|c|c|}
\hline \multirow[b]{2}{*}{ No. } & \multirow[b]{2}{*}{ Kecamatan } & \multicolumn{2}{|c|}{ Jumlah Perkara } \\
\hline & & $\begin{array}{c}\text { Tahun } \\
2015\end{array}$ & $\begin{array}{c}\text { Tahun } \\
2016\end{array}$ \\
\hline 1 & Koba & 43 & 43 \\
\hline 2 & Pangkalan Baru & 21 & 39 \\
\hline 3 & Sungai Selan & 26 & 30 \\
\hline 4 & Simpang Katis & 31 & 28 \\
\hline 5 & Namang & 23 & 13 \\
\hline 6 & Lubuk Besar & 17 & 21 \\
\hline & Total & 161 & 174 \\
\hline
\end{tabular}

\section{Faktor Ekonomi}

Secara nasional, dari 255 juta penduduk Indonesia, 126,9 jutanya adalah kaum perempuan. Tingkat pendidikan kaum perempuan sebanyak $34,7 \%$ nya adalah SLTA keatas. Dari angka ini terdapat 93,3 juta dari total jumlah perempuan berada pada usia kerja dan 45,6 juta jiwa merupakan angkatan kerja. Berdasarkan data-data tersebut dapat menunjukkan bagaimana tingginya angka perempuan yang ikut berpartisipasi dalam ranah publik atau ekonomi. Sebanyak $37,2 \%$ dari jumlah penduduk Indonesia yang bekerja adalah kaum perempuan yang bergerak diberbagai sektor. Sektor informal menempati posisi terbanyak yakni mencapai 55,4\%. Sektor informal ini mencakup berbagai bidang mulai dari membuka usaha sendiri (UMKM) dan sebagai buruh.

Perempuan dengan perekonomian pada dasarnya tidak dapat dipisahkan dan diabaikan begitu saja. Keterlibatan perempuan dalam ranah ekonomi inilah yang pada akhirnya dapat meningkatkan perekonomian keluarga. Akan tetapi tidak sedikit karna persoalan keterlibatan perempuan dalam ranah ekonomi inilah yang juga menjadi salah satu faktor pemicu terjadinya tindak kekerasan dalam rumah tangga.

Pada perempuan yang memiliki aktivitas ekonomi pada ranah formal (bekerja di institusi) dan secara gaji lebih tinggi atau mapan dari suami, cenderung memunculkan rasa minder atau gengsi pada pihak laki-laki. Selain itu tidak sedikit juga yang menyatakan bahwa kadangkala sang istri menjadi tidak optimal dalam mengerjakan pekerjaan domestik dan cenderung menggunakan jasa asisten rumah tangga atau jasa penitipan anak bagi yang memiliki anak kecil. Kondisi tersebut memicu terjadinya percekcokan antara suami dengan istri dalam rumah tangga. Dimana suami merasa istrinya tidak dapat menjalankan tugas dan kewajibannya dengan baik. Keadaan ini pada awal-awalnya memunculkan sikap yang memunculkan tindak kekerasan mulai dari verbal hingga non verbal/fisik.

Data di lapangan juga menunjukkan adanya kondisi yang sebaliknya yakni dimana lakilaki sebagai suami memiliki status pekerjaan dan penghasilan yang relatif lebih mapan. Pada keadaan ini adanya kecenderungan suami melarang istrinya untuk bekerja atau terlibat dalam ranah ekonomi dan hanya fokus pada pekerjaan domestik. Pada saat yang sama, tidak sedikit dari para suami informan menyatakan bahwa suami atau laki-laki cenderung memiliki perempual idalman lain atau selingkungan. Tindakan yang diambil suami inilah yang sudah pasti memunculkan adanya pertikaian atau pertengkaran dan tidak sedikit berujung pada adanya tindak kekerasan yang dilakukan suami/ laki-laki pada istrinya.

Ketika kondisi ekonomi mengalami perubahan atau menurun, para informan (para istri) menyatakan bahwa kadang suaminya mulai sering marah tanpa alasan. Situasi akan semakin tidak baik kalau sang istri tidak memiliki pekerjaan diluar rumah yang dapat membantu perekonomian keluarga. Sehingga ketika suami mengalami kesulitan dalam pendapatan maka akan cenderung melakukan kekerasan baik yang sifatnya verbal maupun non verbal.

\section{Faktor Usia Pernikahan}

Faktor lain yang memepengaruhi terjadinya tindak kekerasan dalam rumah tangga yaitu usia pernikahan. Usia pernikahan ini mencakup dua hal yaitu lamanya pernikahan dan umur ketika menikah. Salah satu yang dinilai ada korelasi 
dengan terjadinta peningkatan angka KDRT yaitu umur ketika menikah atau yang disebut dengan pernikahan dini.

Fenomena pernikahan dini ini memunculkan permasalah tersendiri bagi suatu daerah bahkan negara. Bangka Belitung merupakan salah satu daerah yang memiliki angka pernikahan dini cukup tinggi. Data nasional menunjukkan bahwa angka pernikahan dini di Indonesia terbilang cukup tinggi dan terus mengalami peningkatan. Berikut angka pernikahan usia dini yang masuh dalam lima besar nasional :

Tabel 2. Jumlah Prosentase Angka Pernikahan Dini di Indonesia Tahun 2016

\begin{tabular}{|c|l|c|}
\hline No. & \multicolumn{1}{|c|}{ Provinsi } & Persentase (\%) \\
\hline 1 & Kalimantan Tengah & 52,1 \\
\hline 2 & Jawa Barat & 50,2 \\
\hline 3 & Kalimantan Selatan & 48,4 \\
\hline 4 & Bangka Belitung & 47,9 \\
\hline 5 & Sulawesi Tengah & 46,3 \\
\hline
\end{tabular}

Sumber : CNN 2016

Berdasarkan tabel 2 tersebut menunjukkan bahwa untuk daerah Bangka Belitung angka pernikahan dini masih cukup besar. Kondisi tersebut searah dengan data yang menyebutkan bahwa angka perceraian juga relatif tinggi. Angka ini seolah menunjukkan bahwa semakin tingginya angka pernikahan dini maka berdampak pada makin tingginya angka perceraian. Angka perceraian yang terjadi khususnya di Bangka Belitung terus mengalami peningkatan. Data Pengadilan Agama (PA) menyebutkan bahwa gugatan perceraian banyak diajukan dari pihak istri (perempuan) dan rata-rata terkait adanya kasus tindak kekerasan dalam rumah tangga yang dilakukan oleh suami (laki-laki).

Tindak kekerasan terjadi pada keluarga muda yang melakukan pernikahan dini disinyalir karena adanya faktor ekonomi sebagai salah satu pemicunya. Dimana kondisi perekonomian keluarga muda ini kurang stabil dan mental yang juga belum stabil kala menghadapi perubahan perekonomian dalam keluarga. Perekonomian yang melatarbelakangi tindak kekerasa initernyata tidak melulu pada kasus penurunan ekonomi melainkan persoalan peningkatan ekonomi. Kala perekonomian keluarga mengalami peningkatan dan ketidakseimbangan antara pendapat istri maupun suami (yang kebetulan sama-sama bekerja) menjadi pemicu mulai terjadinya percekcokan antara suami istri yang tidak sedikit berujung pada tindak kekerasan.

Faktor yang kedua yang menyebabkan disharmonis pada keluarga yakni terkait lamanya usia perkawinan. Permasalahan kedua ini terjadi pada keluarga yang sudah relatif lama menjalani ikatan pernikahan atau berumah tangga. pada beberapa kasus semakin lama usia pernikahan maka kondisi ekonomi semakin stabil. Kestabilan bahkan kelebihan ekonomi ini juga memicu terjadinya tindak KDRT yang mayoritas terjadi karena adanya faktor perselingkuhan baik pada suami atau istri. Pada sisi lain yang kondisi ekonominya tidak juga menjadi stabil atau tercukupi akan semakin mempertinggi potensi terjadinya tindak KDRT dalam masyarakat. Dengan demikian,usia pernikahan pada dasarnya mempengaruhi tingkat kestabilan dalam rumah tangga dan salah satu faktor pemicu terjadinya tindak KDRT. KDRT disini secara mayoritas pihak perempuan atau istrilah yang senantiasa menjadi korban.

Kondisi tersebut seolah menjadi sebuah pengukuhan dimana keluarga menjadi ranah domestik yang sangat rentang terhadap terjadinya tindak kekerasan pada perempuan.

\section{Bentuk Kekerasan Dalam Rumah Tangga}

Membahas kekerasan tentunya sangatlah luas dan tidak cukup jika sekedar mendefinisikannya saja. Banyak tokoh yang mencoba mendefinisikan maupun mengklasifikasikan berbagai macam bentuk tindak kekerasan. John Galtung (2003) mengklasifikasikan bentuk kekerasan ke dalam tiga bentuk. Pertama, kekerasan langsung. Kekerasan ini disebut juga sebagai sebuah peristiwa dari terjadinya tindak kekerasan. Kekerasan ini terwujud dalam bentuk tindakan/ perilaku seperti pemukulan, intimidasi, 
pembunuhan dan penyiksaan.

Bentuk yang kedua menurut Galtung adalah kekerasan struktural. Bentuk kekerasan ini terwujud dalam sebuah konteks, sistem dan struktur. Kekerasan ini merupakan kekerasan yang melembaga dan disebut sebagai proses terjadinya kekerasan. Terakhir yang ketiga adalah kekerasan kultural. Kekerasan ini terwujud dalam kehidupan sosial budaya masyarakat yang merasuk pada sistem,sikap, nilai dan norma yang dianut oleh masyarakat. Kekerasan ini terwujud dalam bentuk kebencian, ketakutan, rasisme dan lain sebagainya.

Pada kehidupan kelompok sosial terkecil yakni keluarga, tindak kekerasan pun juga tidak dapat dielakkan. Beberapa penelitian justru menyebutkan bahwa arena domestik menjadi sebuah arena yang "aman" dan bahkan seolah "legal" untuk melakukan tindak kekerasan. Kesemua tindakan tersebut selalu berdalih atas nama ranah privat dan pengabdian ataupun kepatuhan kepada pasangan. Sehingganya tidak sedikit yang merasa tabu dan tidak berani menggugat ketika mengalami tindak kekerasan dalam rumag tangga atau keluarga. Dari sekian banyak bentuk kekerasan yang ada, dalam keluarga atau rumah tangga, bentuk kekerasan yang terjadi jika mengacu pada Galtung maka banyak yang mengalami tindak kekerasan langsung yang dialami oleh perempuan. Dari kekerasan langsung tersebut juga tidak menutup kemungkinan merambah pada kekekrasan struktural dan kultural. Secar garis besar, kekerasan langsung yang terjadi pada rumah tangga dan dialami oleh perempuan dibedakan menjadi dua kategori, yakni kekerasan fisik dan non-fisik.

\section{Kekerasan Non-Fisik}

Bentuk kekerasan yang tidak berdampak langsung pada fisik tetapi dapat menjadi pemicu terjadinya kekerasan fisik yakni kekerasan non fisik. Beberapa ahli menyatakan bahwa kekerasan non fisik ini justru dinilai lebih berbahaya dan memiliki dampak yang relatif cukup lama. Kekerasan non fisik disini yaitu jenis kekerasan yang tidak kasat mata. Artinya, tidak bisa langsung diketahui perilakunya apabila tidak jeli memperhatikan, karena tidak terjadi sentuhan fisik antara pelaku dengan korbannya.

Secara garis besar, kekerasan non fisik ini dibagi menjadi dua, yaitu kekerasan verbal dan kekerasan psikologis atau psikis. Kekerasan verbal merupakan kekerasan yang dilakukan melalui kata-kata. Sedangkan kekerasan psikis yaitu kekerasan yang dilakukan lewat bahasa tubuh seperti mendiamkan, merendahkan, mencibir, memelototi dan lain sebagainya.

Tindak KDRT yang terjadi pada kehidupan sosial masyarakat cenderung diawali dengan adanya tindak kekerasan nonfisik. Dalam kehidupan rumah tangga, berdasarkan data di lapangan informan menyatakan bahwa tidak sedikit awal mulanya terjadi kekerasanfisik dimulai dengan percekcokan. Percekcokan yang terjadi umumnya antara suami dan istri sering bertengkar bahkan melontarkan katakata kasar yang berujung pada rasa sakit hati atau bahkan dendam. Disini menjukkan bahwasannya kekerasan verbal yang terjadi pada pasangan suami istri pada tahap lebih lanjut berdampak pada psikis keduanya. Dengan demikian kekerasan verbal akan berdampak atau merambah pada kekerasan psiskis. Dari bentuk kekerasan inilah yang tidak jarang berujung pada tindak kekerasan fisik. Beberapa informan di lapangan mengemukakan bahwa ketika terjadi percekcokkan, suaminya sering melontarkan kata-kata kasar, cacian, makian bahkan umpatan.

Dari kejadian tersebut, ketika perempuan tidak memiliki power untuk berontak, maka yang terjadi berbagai tindak kekerasanpun dialami. Perempuan berada pada posisi yang cukup sulit. Pada satu sisi kontruksi sosial memandang bahwa perempuan sebagai istri tidak boleh melawan suami. Pada sisi lain perempuan telah mengalami kekerasan yang berlapis. Ketika perempuanmelakukan gugatan, maka lingkungan sekitar sering menilai atau memberi label negatif. Situasi seperti ini yang tidak sedikit membuat perempuat memilih diam ketika mengalami tindak KDRT. 


\section{Kekerasan Fisik}

Kasus KDRT yang terjadi pada keluaraga di pulau Bangka dan masyarakat luas pada umunyaberbentuk kekerasan langsung. Prempuan sebagai korban tidak sedikit yang mengalami kekerasan secara fisik bahkan hingga mengalami luka parah. Kekerasan fisik disini merupakan jenis kekerasan yang kasat mata. Artinya, siapapun bisa melihatnya karena terjadi sentuhan fisik antara pelaku dengan korbannya. Contohnya adalah: menampar, menimpuk, menginjak kaki, menjegal, meludahi, memalak, melempar dengan barang dan lain sebagainya. Data dari informan yang diambil, $72 \%$ dari perempuan yang mengajukan gugatan cerai ke Pengadilan Agama (PA) di Kabupaten Bangka dilatar belakangai karena adanya tindak kekerasan fisik yang dialami oleh perempuan (Anisa, 2016:47-49). Data tersebut menunjukkan bahwa perempuan ketika berada pada ranah domestik pun juga cukup rentan mengalami tindak kekerasan yang bahkan bersumber dari orang terdekatnya.

Pemicu terjadinya tindak kekerasan fisik ini pun sangat bervariasi. Sebagaimana dikemukakan sebelumnya bahwa faktor ekonomi, usia pernikahan dan lamanya pernikahan berpengaruh pada keharmonisan keluarga. Mulai dari hal-hal kecil lingkup rumah tangga yang terjadi pada sebagai pemicu tindak kekerasan. Peran perempuan dalam ranah domestik ini pun menjadi cukup rentan sebagai sumber terjadinya kekerasan. Perempuan dituntut untuk sempurna dalam menangani bergitu banyak peran atau pekerjaan yang ada dalam ranah domestik. Beban yang yang berlebih ini terkadang diabaikan dan tidak dipedulikan oleh suami sehingga suami cenderung tahunya semua beres.

\section{E. Penutup}

Perempuan dan tindak kekerasan seolah-olah menjadi dua hal yang tidak terpisahkan dalam fenomena kehidupan masyarakat. Perempuan senantiasa ditempatka dan diberlakukan sebagai pihak yang seolah-olah lemah dan tidak mampu mandiri. Konstruksi sosial masyarakat yang terus berkembang dinilai menjadi tidak adil bagi perempuan. Keberadaan perempuan senantiasa menjadi ancaman bagi perempuan itu sendiri.

Keluarga merupakan institusi sosial yang harapannya mampu memberikan rasa aman dan nyaman bagi setiap anggotanya. Akan tetapi faktanya justru sebaliknya. Keberadaan perempuan dalam keluarga ini juga menjadu kekhawatiran ataupun masalah yang cukup pelik. Belakangan terakhir justru banyak tindak kekerasan yang dialami oleh perempuan justru di dalam keluarga atau rumah tangganyanya sendiri. Tindakan kekerasan ini dipicu oleh beberapa faktor. Untuk di wilayah Pulau Bangka, tindak Kekerasan Dalam Rumah Tangga (KDRT) yang paling dominan dipicu oleh faktor ekonomi. Faktor ekonomi pun ini juga tidak tanpa sebab. Salah satu sebabnya adalah pernikan yang terlampau dini. Hal ini sekaligus menjadi faktor penyebab kedua dari terjadinya KDRT. Melakukan pernikahan di usia yang relatif muda ini cenderung mempengaruhi kestabilan dalam rumah tangga, baik kestabilan emosi maupun ekonomi. Faktor yang ketiga yakni lamanya usia pernikahan. Usia pernikahan yang sudah lama ternyata berpengaruh bagi tindak KDRT. Pasangan yang sudah lama menikah dan mengalami masalah ekonomi (baik peningkatan maupun penurunan) cenderung menimbulkan masalah baru yakni keberadaan orang ketiga. Hal inilah yang kemudian menyulut percekcokan yang tidak jarang berakhir pada tindak kekerasan yang dialami oleh perempuan.

Berdasarkan uraian tersebut maka dapat disimpulkan bahwasannya arena privat atau ranah domestik yang dibebankan pada perempuan cenderung menjadi ranah terjadinya tindak kekerasan. Kekerasan yang dialami oleh perempuan ini sangat kompleks. Bentuknya sangat variatif. Secara umum dapat dikelompokkan menjadi dua yakni kekerasan fisik dan nonfifik. Tindakan kekerasan inilah yang senantiasa menjadi pemicu munculnya gugatan perceraian yang diajukan oleh pihak perempuan. 


\section{Daftar Pustaka}

Ayu, Radita Wulandari. 2013. Faktor-faktor Penyebab Pernikahan Usia Muda dan Kaitannya Dengan Tindakan Perceraian Pada Masyarakat di Kota Pangkalpinang. Skripsi Sosiologi: UBB.

Artiana, Septi. 2015. Kasus Perceraian di Babel meningkat. http://www.antarababel.com

Budiman, Arief. 2007. Pembagian Kerja Secara Seksual. Yayasan Obor: Jakarta.

C.Ollenburger, Jane dan Helen A. Moore. Sosiologi Wanita. Rineka Cipta: Jakarta.

Choiriah, Muchlisa. 2016. Indonesia Darurat Perceraian. https://www.merdeka.com.

Djannah, Fathul dkk. 2007. Kekerasan Terhadap Istri. LKIS: Yogyakarta.

Hadiwardoyo, Purwa. 2006. Tujuh Masalah Sosial Aktual: Sikap Gereja Katolik. Kanisius: Yogyakarta.

Ihromi. 2004. Bunga Rampai Sosiologi Kelurga. Yayasan Obor: Jakarta. 